\title{
Development of supply chain management models in rice production to improve food endurance and security in Demak Regency
}

\section{Nurul Imani Kurniawati (D), Riandhita Eri Werdani, Stacia Reviany Mege}

Vocational Schools, Diponegoro University, Indonesia

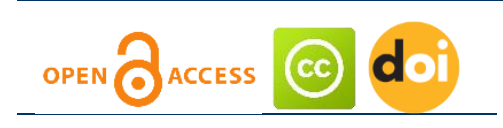

Article history:

Received: July 10, 2020

1st Revision: August 23,

2020

Accepted: October 31,

2020

\section{JEL classification: \\ E31 \\ Q11}

DOI:

10.14254/jems.2020.5-2.7

\begin{abstract}
Food is the main basic needs for human that must be fulfilling at all times. The right to obtain food is one of human right, as it stated in the article 27 of the 1945 Constitution and in the Rome Declaration (1996). The aim of this study is to find out and analyze the development of supply chain management models that are used to maximize rice production in order to improve food security and security in Demak Regency. The methodology that used of this study is descriptive qualitative with the data collection method used in-depth interviews and Focus Group Discussion (FGD) and literature study. The result of this study indicate that it can increase rice production and increase the rice fulfillment ratio around $12 \%$ at the end of the 2032 period and the scenario with the efficiency of the rice supply chain can reduce the logistics costs between farmers and rice traders around $14.3 \%$. The conclusion of this study is to increase the ratio of rice fulfillment and creates the efficiency in supply chain management. This shows that based on parameters changes by increasing the value of crop agro-input and extensification scenarios which can increase the rice production per year and rice fulfillment ratio, while scenarios with rice supply chain efficiency can reduce the logistics costs between farmers and rice traders around $14.3 \%$. While the rice prices were also affected and had a price reduction ratio of $3.75 \%$.
\end{abstract}

Keywords: rice, supply chain, management, Demak Regency, logistic, distribution. 


\section{Introduction}

Food is the main basic needs for human that must be fulfilling at all times. The right to obtain food is one of human right, as it stated in the article 27 of the 1945 Constitution and in the Rome Declaration (1996). The consideration underlies the publication of constitution No. 7/1996 about food. As the basic needs and one of the human rights, food has a meaning and role that is very important for the life of a nation food. Food stock is smaller than its needs which can create the economic instability. Several of social and politic turmoil, can also occur if food security is disrupted. This critical food condition can even endanger the economic stability and National stability.

For Indonesia, food is often identified with rice because this type of food is the main staple food. The experience has been proven that disruptions to food security such as skyrocketing rice prices during the 1997/1998 economic crisis, which developed into a multidimensional crisis, and has triggered the social insecurity which endangers the economic and national stability.

Besides it, rice has a strategic value because rice is the most important staple food; it consumed by more than 95\% Indonesia's population. Inadequate supply of rice can cause a country's economic, social and political instability. In the economic field, the rice industry has a great influence in terms of employment. The rice industry can absorb employee with serving the job opportunity for 21 million families through rice farming. Whereas, for social politics as unifying the nation, and realizing discipline and security. Moreover, it also affects the environment in terms of maintaining the water use and cleanliness of the air. As for health, rice is also the main sources of nutrition fulfillment which includes calories, protein, fat and vitamins (Muhammad \& Sumarauw, 2014).

Considering the importance of rice, the government always strives to improve and maintain the food endurance, especially the source from increasing the domestic rice production. But in reality, increasing the food endurance in Indonesia is often not optimally. One of the problems in distribution of rice related to distribution occurs because there is a uneven flow of goods because the distribution facilities and infrastructure are still limited; remote locations between producers, suppliers and consumers; the mode of transportation used for transporting rice; and the quality of infrastructure that is still not optimal, causing costs to be expensive. The optimal distribution in this case can be achieved through the implementation of supply chain management concepts (Sumangkut, 2013).

Supply chain management is a combination of planning, coordination and control of the whole process, as well as business activities in supply chain to fulfilling the consumer needs at the lowest prices (Chopra \& Meindl, 2007). Supply chain management describes the coordination of the entire supply chain activities, the starting from raw materials and ending with goods until in the hands of consumers. The supply chain is including the suppliers, the manufacture of company and/or service provider, and distributor, gorsier, and/or retailer delivering the product and/or services to end consumers (Heizer \& Render, 2014).

Indonesia has 8 (eight) rice-producing regions. The eight regions are West Java, Central Java, East Java, Yogyakarta, West Nusa Tenggara, South Sulawesi, Lampung and South Sumatra. The region of main rice producer is Java, especially Central Java. Central Java is surrounded by volcanic mountains and abundant the water sources making Central Java a fertile agricultural land and full of potential to increase national rice supply. One of them is located in Demak Regency, Demak Regency's area of 89,743 ha consisting mostly of agricultural land. As many 58.29 percent of Demak is a rice land. This makes it a lot of residents who work as farmers because most of the area is in the form of potential rice fields, namely 54,076 ha (58.29 percent) and the rest is a dry land (Hikam, 2019).

Thus, most of the land allotment in Demak Regency is for irrigated rice fields where most of it belongs to the technical irrigation category so that it is very potential for the development of agricultural and other agro-industry businesses. With the kind of soil and climate conditions, Demak produces a number of superior commodities including rice, corn, cassava, yams, peanuts, green beans, soybeans and sorghum. From these superior commodities, rice is the most production in Demak Regency, this makes Demak is a rice production centre. The main commodity types of rice and pulses in the district of Demak 2018, such as rice production is 608.532 , corn is 166.876 , cassava is 3.208 , yams is 1.658 , peanuts is 122 , green beans is 25.540 , soybean is 177 , and sorghum is 689 .

The production of rice aims to maintain the inventory stability, maintain and increase the production optimally with the purpose of maintaining the security and endurance of food production in the region, every consumer demand for rice can be fulfilled properly. Every village in Demak Regency has a great potential in supporting regional economic development and one of the contributing regions for rice production, both in Demak Regency and outside the region (Saptana, Suryani, \& Darmawati, 2019). 
The aim of this study is to develop a supply chain management models to maximize rice production and increasing food endurance and security in Demak regency. This study is to find out and analyze the development of supply chain management models that are used to maximize rice production and improve food endurance and security in Demak regency.

\section{Literature review}

\subsection{Food Endurance and security}

The food endurances can be said as ability of a nation to guarantee that all the entire population obtains adequate, safe, decent quality and halal food by optimizing utilization and based on diversity of local resources.

\subsection{Logistic Management}

Logistic is a series of activities to get and place the goods from planned place and time. Another logistic meaning is a set of functional activities (transportation, inventory control, and other) a company carrying out in the process of converting raw materials into finished products.

\subsection{Supply chain}

Supply chain is a series of relationship between the companies and activities that implemented the distribution of goods or services from the place of origin to the place of the buyer or customer (Assauri, 2011).

\subsection{Supply chain management}

Calantone, Cavusgil, Schmidt and Shin (2004) stated that supply chain management is design planning and information, control and material flow in along the supply chain in order to efficiently meet customer needs now and in the future. Heizer and Render (2004) also stated that supply chain management is the management of activities for which procurement materials and services, transform it become semi-finished goods and final products and deliver products through a distribution system.

\subsection{Previous study}

This research is conducted by Talumewo (2014).

This research is conducted by (Pondaag, Kawet, \& Talumewo, 2014) carrying out the research entitled supply chain analysis of the availability of raw materials in the fast food industry in KFC multimart ranotana. The methodology that used is qualitative, in the qualitative research, the population and sample which taken is called an informant. Determination of informant is determined based on the research framework which is the management of the KFC Multimart Manado branch.

The results indicated that supply chain management has an impact on the supply of sufficient and needed raw materials and quality where with a good supply chain management will make inventory will always be maintained and meet the needs and demands when needed, especially in KFC Multimart Manado branch.

This research is conducted by Theis (2013).

This research is conducted by (Theis, 2013) carrying out the research entitled supply chain management towards the fulfillment of fuel needs in gas stations in Manado. In the research used a descriptive qualitative analysis method. The place of the research is Pertamina Bitung Depot, the result showed that Pertamina Bitung Depot distribute Refined Fuel Oil in large numbers every year, then consumers specifically for gas stations in Manado do not need to worry about the scarcity of stocks that can interfere with community activities. 


\section{Methodology}

This study is a descriptive method, with more description from the result of interviews and documentation studies with using survey methods that illustrating, explain, and interpret a phenomenon that occurs in an object and the qualitative data, the type of this research is descriptive qualitative that used means to obtain the information on the implementation of supply chain management performance as a strategy that used in depth and comprehensively.

The data that obtained will be analyzed in qualitative and descriptive form. The location of research was conducted in Demak regency who focused on rice farmers, rice mills and rice traders. The research was conducted in December 2019 until March 2020 by conducting field surveys and developing research with sources obtained from secondary data.

In this study is using the primary and secondary data sources. The primary data used in this study were obtained from the interview with village officials and farmers in Demak Regency. The secondary data of this study were obtained from the literature review, previous literature study, books, internet and other which supported the research. The research is including main team, which is the team of lecturers and the field team of students.

Data analysis technique that used in this research is using the steps that argued by (Bungin, 2011), as below:

\section{Data collection}

The data collection is the integral part from the data analysis activities. The data collection activities in this research are using interviews and documentation studies. The data collection techniques in this study were carried out with the following techniques: a) documentation; b) interview (in-depth interview); c) observation; and d) Focus Group Discusion (FGD): by including government and non-government parties.

\section{2. data reduction}

Data reduction, as defined as decision making process, focuses on simplifying and transforming rough data that arises from written records in the field. Reduction is implemented since data collection begins by making summaries, coding, tracing themes, creating clusters, writing memos and so on with the intention of setting aside irrelevant data/information.

3. display data

Data display is description of a collection of structured information that gives the possibility of drawing conclusions and taking action. Presentation of qualitative data is presented in the form of narrative texts. The presentation can also be in the form of matrices, diagrams, tables and charts.

4. conclusion drawing and verification

This is the final activity from data analysis, it can conclude in the form of interpretation activities, which is finding the data that has been presented. In this explanation, qualitative data analysis is an ongoing, repeated and ongoing effort. The problem of data reduction, data presentation and drawing conclusions/verification is a success illustration as a series of related analysis activities.

\section{Result and discussion}

Demak Regency in 2019 now has a population of 1.132 million people and an area of 89,743 hectares, holds millions of potential. To maximize some those various potentials, Demak Regency officials and government is focusing to develop five sectors which is underpin regional progress. The five sectors are agriculture, marine and fisheries, education and health, tourism and Micro, Small and Medium Businesses (UMKM).

The entire pillars are the priority programs that can rid the citizenry from poverty, reduce unemployment and increase the community income. As in the previous year, the agriculture sector became one of the pillars which received main concern considering that the most of Demak community still relying on the source of income from this sector. From 89.743 hectares of the total area in Demak Regency, $56.74 \%$ or 52,315 hectares of which are the rice fields with plant pattern of rice-crop plant. Rice commodity is the commodity which is demanded by the central government for self-sufficiency in a special rice, maize and soybean effort program (Upsus Pajale).

With position of Demak regency as food barns in Central Java and the third food buffer area in Central Java after Cilacap and Grobogan, because the government apparatus along with Demak Regency Agriculture and Food Office always striving to encourage to encourage progress in this sector expected that rice crop productivity will continue to increase and have good quality. One of 
them by notice to improving rice production with aims of maintaining the food security and endurance of rice productions in the Demak Regency area.

In this discussion, it will be conveyed about how the Implementation of Demak Rice Production Supply Chain, how to coordinate the harvest time, the amount of harvest and the selling price of rice from farmers in Demak, which parties are involved in the rice production supply chain and what are the obstacles in implementation rice production supply chain is mainly related to transportation in the context of increasing food security and security in Demak Regency.

\subsection{The development supply chain management models in rice production to improve food endurance and security in Demak Regency}

In this study, the alternative solution that takes is used modeling and simulation as a tool for providing support for planning, analyzing, and evaluating systems using dynamic simulation models scenario analysis that estimates which is expected to improve the current condition of the rice supply chain. Through a dynamic simulation model, analysis on the system implemented by considering the existing historical data, and designing scenarios that are expected to improve the current condition of the rice supply chain. It can overcome the existing problems, can help to achieve the target of rice supply from the government, and can optimize the rice production in Demak District which is the third buffer zone of food security in Central Java.

It expected from this research obtain the consideration related the rice stocks to increase the ratio of rice fulfillment and create efficiency in supply chain management. Modeling and simulation in this study are used to availability model of rice in Demak Regency. With modeling rice commodities to improving food security and endurance, it is expected from this study, the simulation result can help the consideration related the rice stocks to increase the rice fulfillment ratio and creates efficiency in supply chain management.

Based on the research conducted by (Mulyadi, 2011) It is recommended for strategic commodities or basic needs (such as: sugar, flour, salt, cooking oil, fertilizer, rice, medicine, cement, fuel and LPG) to establish an effective supply chain and efficient can be done in the following ways:

a. To make Streamlining the supply of commodities and demand (rice) can be fulfilled, this can be seen from the fulfillment ratio that was successfully fulfilled;

b. To make streamline distribution and manufacturing in order to obtain these commodities at affordable prices

\section{A. Conceptual Systems for Model Formulation and Rice Supply Chain Simulation scenario result}

It stated by (Campuzano \& Mula, 2011) that model is the illustration of relation or results from the reality. Modeling is made in a simple illustration, involving the mapping problems process from the reality to the model in the world model. The problems in rice stocks are is a fairly complex system problem involving various components and variables in interacting and integrated with each other. National rice stocks can be seen as a system dynamics matter that changes over time and influenced by factors that are also dynamic. The purpose is to see the pattern of rice stocks in the context of improving national food security and security with various alternative development scenarios in accordance with the conditions.

\section{B. Simulations in the supply chain}

The simulation in the supply chain is described as a system that certain process that tested to analyze and learn with observed certain processes in the real supply chain until the results are in accordance with the needs and wants. effect (causal) which affects the structure in the system so as to form a causal diagram (causal loop), formulated in a flow chart (stock and flow) and supply chain is simulated into a useful tool for understanding the supply chain network consisting of the function of material procurement, transformation from raw materials to finished products and then the process of distribute it.

The dynamic system regarding the rice stock, model design, simulation and analysis implemented with referring to purpose and using the scenario in each models. Using the scenario to achieve the optimal results is one of the traditional methods for handling the cases that contain the uncertainty. The simulations in the supply chain can shows how the important variables in the system interact with each other. The relation and interaction between variable is stated in a caustic diagram. This is can also be used in implementing the new situations or draft scenarios, where it is found the uncertainty in the form of information, to the decision which want to apply.

The development of dynamic system models in this study is into several steps as follows: 
1. Arranging variable into a caustic diagram

The first step is arranging the variable through a caustic diagram or commonly called causal loop diagram. The models result of caustic diagram to rice stocks to increase the fulfillment ratio and efficiency of supply chain management, can be seen in the Figure 1:

Figure 1: Causal Loop Diagram (Caustic Diagram)

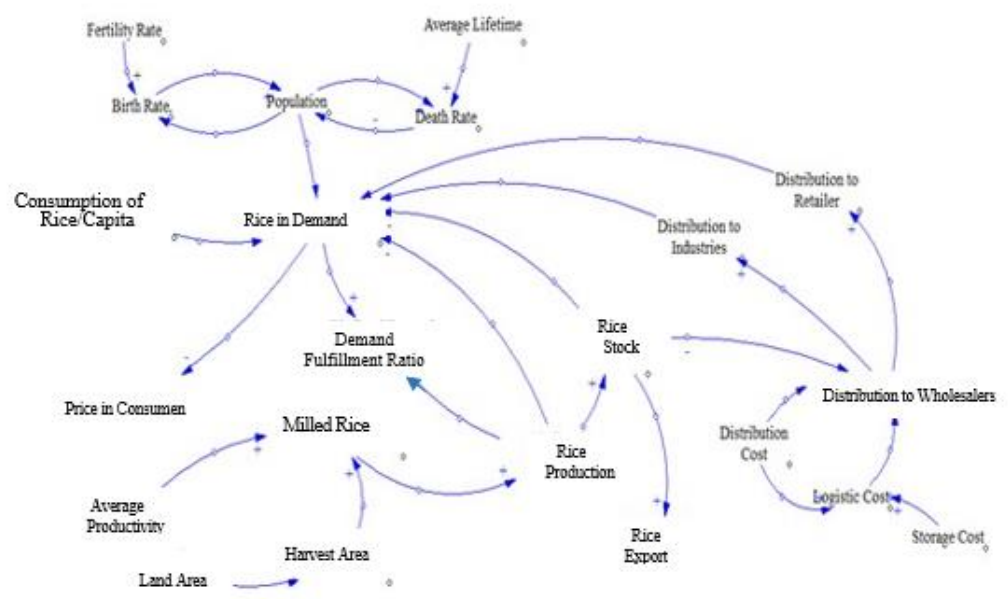

2. Making a model by linking the relationships between variables in a flow diagram then simulating the model.

In this step is making stock and flow diagram of rice stocks to increase the fulfillment ratio and efficiency of national rice supply chain management. The flow diagram is made to illustrate how the amount of rice production can meet consumer demand. In preparing this flow diagram found 7 submodels there are:
a. Sub-Model Population
b. Sub-Model Demand
c. Sub-Model Rice Production
d. Sub-Model Rice Inventory
e. Sub-Model Rice Cost
f. Sub-Model Rice Logistic Cost
g. Sub-Model Rice Price in Consumer

3. Verification and validation of the model to determine whether the model is in accordance with real conditions.

After making models, the next step is testing the model. The model testing is including two important stages, which is validation and verification. In verification model will carry out the test whether the model that has been made can describe the conceptual model clearly and is free from errors. While model validation is implemented after the simulation model is verified and purpose to see whether model is already described the real condition or not.

During validation phase, it will be implementing the test process model. The model is valid when it has no significant differences from the real system that observed. To ensure that model is in accordance with existing conditions, validation is carried out as shown in Table 1 . From the table it can be seen the model is said to be valid if the mean comparison $<5 \%$ and error variance $<30 \%$.

\begin{tabular}{lcc} 
Table 1: Validation base model & & \\
Variable & Mean Comparison & Error Variance \\
\hline Rice Production & $4,75 \%$ & $6,5 \%$ \\
Demand & $3,23 \%$ & $9,6 \%$ \\
Productivity & $4,83 \%$ & $24,65 \%$ \\
Population & $1,79 \%$ & $9,63 \%$ \\
\hline
\end{tabular}

Source: Own study 
From all the validation result above, all variables mean comparison $<5 \%$ and error variance $<30 \%$ so that the model can be said to be valid.

4. After the model is declared valid, a scenario is made from the initial model

After base model has been validated and verified, in the next stage is scenario, where the scenario becomes a proposed system improvement, in accordance with the initial goal of making a dynamic system model for national rice stocks. Scenarios can be made by adding variables and parameters that have a dominant influence through the entire base model, for further determine the impact that changes through other variables. The scenario created aims to increase the rice stocks ratio through the rice productivity improvement, and the other scenario aims to minimize logistics costs by streamlining the distribution chain of rice production, as below:

a. Scenario 1 (parameter): aims to increase rice production by improving the value of agro input crops such as increasing the use of new improved seeds, applying a balanced fertilizer according to the level of soil fertility and harvest technology.

b. Scenario 2 (Land Intensification): aims to increase the rice production by opening a new rice harvesting land.

c. Scenario 3 (Streamlining the Distribution Chain): Aiming to minimize logistical costs that arise and increasing with the length of the distribution chain of rice production.

Figure 2: Sub-Model Scenario 2

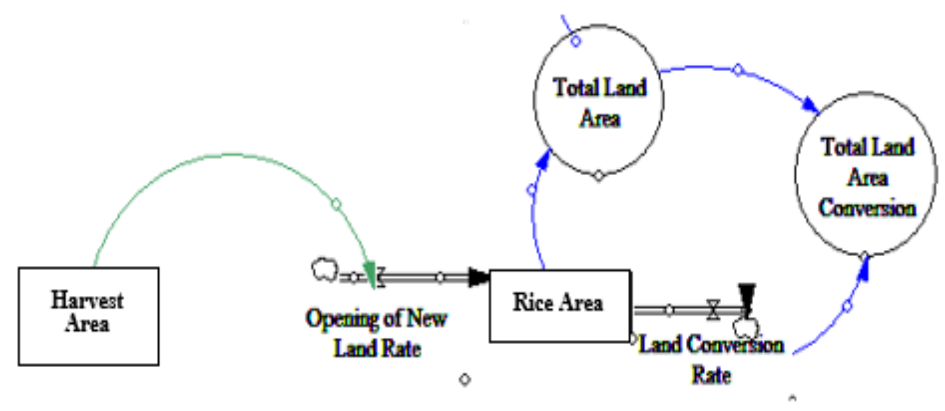

\subsection{Scenario result}

The simulation results show that based on changing parameters by increasing the value of crop agro-input can increase the rice production per year and the rice fulfillment ratio is predicted to also increase to 12 million tons at the end of the 2032 period, Land Intensification scenarios can increase rice production and improving rice stocks ratio around 12\% in the end period of 2032 and efficiency scenario of the rice supply chain can reduce logistics costs between the farmers and rice traders by around $14.3 \%$. While the rice places was also affected and compare a price reduction ratio of $3.75 \%$. The results of each scenario can be seen in Figure 5 :

Figure 3: Scenario Result 1

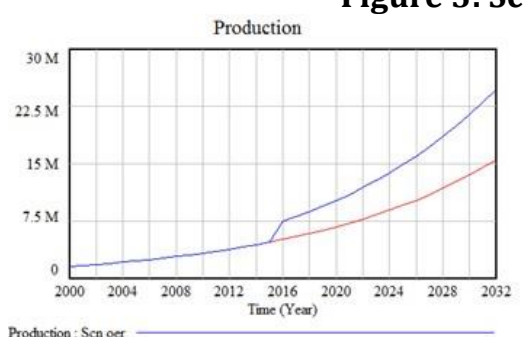

Production: Scn oer

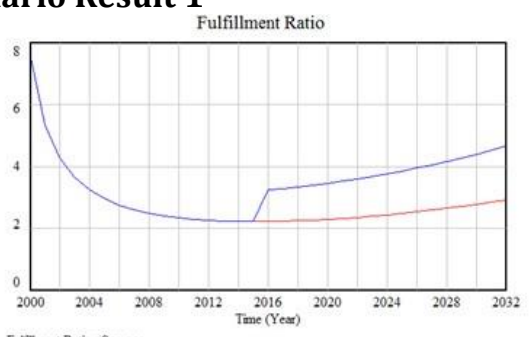

Futsiliment Ratio: Scn oer 
Figure 4: Scenario Result 2
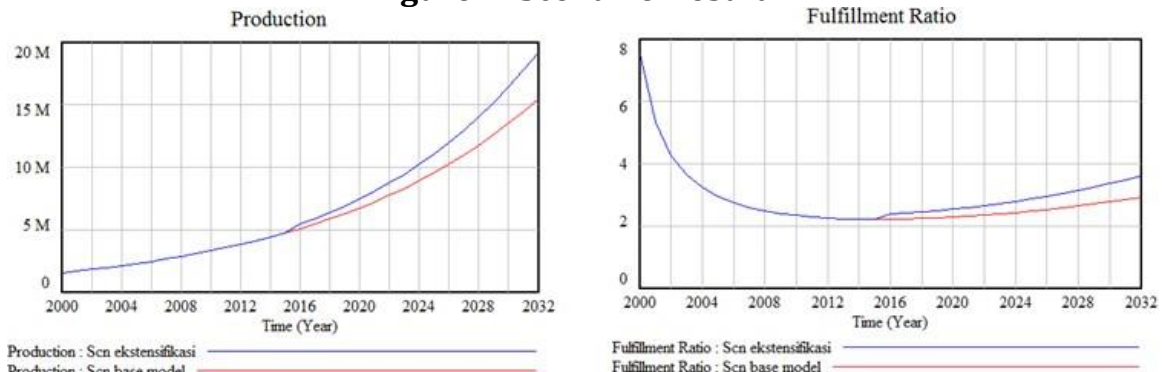

Figure 5: Scenario Result 3
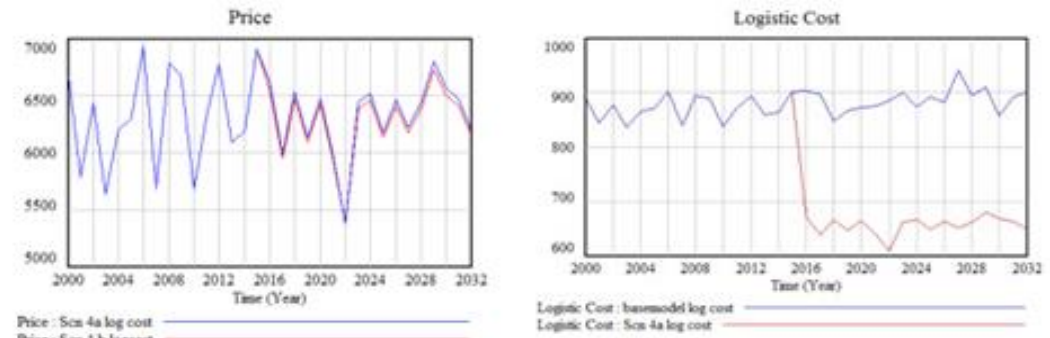

\section{Conclusion and Suggestion}

\section{Conclusion}

Based on the research which implemented, it can be concluded several things as below:

The development of the Rice Production Supply Chain Management Model in the framework of Improving Food Security and Security in Demak Regency implemented using a dynamic system model with the purpose obtaining consideration related to the rice supply to increase the ratio of rice supply and creates efficiency in supply chain management. Dynamic system modeling regarding rice availability, model design, simulation and analysis implemented with reference to purpose and use of scenarios in each model. The scenarios that used is Scenario 1 (Parameters), Scenario 2 (Land Extensification) and Scenario 3 (Streamlining the Distribution Chain). The development of this dynamic system model shows that based on parameters changes by increasing the value of crop agroinput and extensification scenarios can increase rice production per year and rice fulfillment ratio, while scenarios with rice supply chain efficiency can reduce logistics costs between farmers and rice traders around 14, 3\% While the price of rice was also affected and price reduction ratio of 3.75\%.

\section{Suggestion}

Some suggestion below that can gives by researchers based on the research result as below:

In the development the supply chain model of rice production using a dynamic system, it can be used as a reference for simulating rice stocks in increasing supply fulfillment ratios and efficiency of supply chain management and can be used as a reference in determining policy. But, it needs for re-research with the purpose to improve system using variety from the other supporting scenarios. It expected the availability of rice by increasing the ratio of rice stocks and supply chain management efficiency can be more effective.

\section{Citation information}

Kurniawati, N. I., Werdani, R. E., \& Mege, S. R. (2020). Development of supply chain management models in rice production to improve food endurance and security in Demak Regency. Economics, Management and Sustainability, 5(2), 103-111. doi:10.14254/jems.2020.5-2.7 


\section{References}

Assauri, S. (2011). Manajemen Produksi dan Operasi. Jakarta: Lembaga Penerbit FEUI.

Bungin, B. (2011). Penelitian Kualitatif. Jakarta: Kencana Predana Media Group.

Calantone, R. J., Cavusgil, S. T., Schmidt, J. B., \& Shin, G. C. (2004). Internationalization and the dynamics of product adaptation - An empirical investigation. Journal of Product Innovation Management. https://doi.org/10.1111/j.0737-6782.2004.00069.x

Campuzano, F., \& Mula, J. (2011). Supply Chain Simulation. In Supply Chain Simulation. https://doi.org/10.1007/978-0-85729-719-8

Chopra, S., \& Meindl, P. (2007). Supply Chain Management. Strategy, Planning \& Operation. In Das Summa Summarum des Management. https://doi.org/10.1007/978-3-8349-9320-5_22

Heizer, J., \& Render, B. (2004). Operations Management, 7th Edition. New Jersey: Pearson Education, Inc.

Heizer, J., \& Render, B. (2014). Operation Management Sustainability and Suplly Chain Management: 11th Edition. New Jersey: Pearson Education, Inc.

Hikam, H. A. Al. (2019). 8 Provinsi Jadi Lumbung Beras RI, Ini Daftarnya. Retrieved February 13, 2020, from Berita Ekonomi Bisnis website: https://finance.detik.com/berita-ekonomi-bisnis/d4535073/8-provinsi-jadi-lumbung-beras-ri-ini-daftarnya

Muhammad, M. R., \& Sumarauw, J. S. B. (2014). Evaluasi Kinerja Manajemen Rantai Pasok Pada Pemasok Daging Ayam, Jeky Pm. Emba.

Mulyadi, D. (2011). Pengembangan Sistem Logistik Yang Efisien Dna Efektif Dengan Pendekatan Supply Chain Management. Jurnal Riset Industri.

Pondaag, J., Kawet, L., \& Talumewo, P. (2014). Analisis Rantai Pasok Ketersediaan Bahan Baku Di Industri Jasa Makanan Cepat Saji Pada Kfc Multimart Ranotana. Jurnal Riset Ekonomi, Manajemen, Bisnis Dan Akuntansi. https://doi.org/10.35794/emba.v2i3.5918

Saptana, N., Suryani, E., \& Darmawati, E. (2019). Kinerja Rantai Pasok, Dinamika, dan Pembentukan Harga Beras di Jawa Tengah. Analisis Kebijakan Pertanian. https://doi.org/10.21082/akp.v17n1.2019.39-58

Sumangkut, A. (2013). Kinerja Supply Chain Management Dan Strategi Informasi Pada Pt. Multi Food Manado. Jurnal Riset Ekonomi, Manajemen, Bisnis Dan Akuntansi. https://doi.org/10.35794/emba.v1i3.1900

Theis, R. (2013). Pengelolaan Rantai Pasokan Terhadap Pemenuhan Kebutuhan Bbm Pada Spbu Di Kota Manado. Journal of Chemical Information and Modeling. https://doi.org/10.1017/CB09781107415324.004

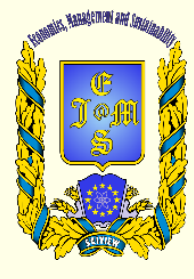

(c) 2016-2020, Economics, Management and Sustainability. All rights reserved.

This open access article is distributed under a Creative Commons Attribution (CC-BY) 4.0 license.

You are free to:

Share - copy and redistribute the material in any medium or format Adapt - remix, transform, and build upon the material for any

purpose, even commercially.

The licensor cannot revoke these freedoms as long as you follow the license terms.

Under the following terms:

Attribution - You must give appropriate credit, provide a link to the license, and indicate if changes were made.

You may do so in any reasonable manner, but not in any way that suggests the licensor endorses you or your use.

No additional restrictions

You may not apply legal terms or technological measures that legally restrict others from doing anything the license permits.

Economics, Management and Sustainability (ISSN: 2520-6303) is published by Scientific Publishing House "CSR",

Poland, EU and Scientific Publishing House "SciView", Poland

Publishing with JEMS ensures:

- Immediate, universal access to your article on publication

- High visibility and discoverability via the JEMS website

- Rapid publication

- Guaranteed legacy preservation of your article

- Discounts and waivers for authors in developing regions

Submit your manuscript to a JEMS at http://jems.sciview.net or submit.jems@sciview.net

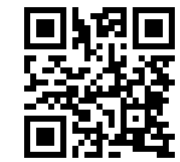

